\title{
Human Nature Interaction in Ifugao Satoyama Landscape; UNESCO Inscribed Heritage Site and GIAHS
}

\author{
Vicky Cadalig- Madangeng (Corresponding author) \\ Ifugao State University \\ Nayon, Lamut, Ifugao, Philippines \\ E-mail: vikicad@yahoo.com
}

Received: March 27, 2015 Accepted: April 6, 2015 Published: June 24, 2015

doi:10.5296/ijch.v2i1.7850 URL: http://dx.doi.org/10.5296/ijch.v2i1.7850

\begin{abstract}
The photography of satoyama landscape was made to document and appropriately label the different heritage sites \& GIAHS in Ifugao to include the various human interactions with regards to their series of activities in the rice terraces. Descriptive analyses of the photographs were presented in narrative form in a simple approach that can be understood and be appreciated by every audience.

Satoyama landscapes found in Ifugao were built and developed through prolonged interaction between humans and their surrounding ecosystems, as one of grounds that Ifugao is in the UNESCO Heritage Sites (In 1996, the Ifugao Rice Terraces was declared a World Heritage site by the UNESCO) and the only Globally Important Agricultural Heritage Site in the Philippines (GIAHS) and one of the few first listed GIAHS in the world. GIAHS are defined as " Remarkable land use systems and landscapes which are rich in globally significant biological diversity evolving from the co-adaptation of a community with its environment and its needs and aspirations for sustainable development" (FAO 2002).

The researcher used the photos as resources of analysis, defined and labeled the landscapes and human interactions in the heritage sites. The five Ifugao world heritage clusters (Hungduan, Batad, Bangaan, Nagacadan, and Mayoyao,) were considered in this study.
\end{abstract}

Keywords: Rice Terraces,Inscribed Heritage Sites, Land use systems and landscapes

\section{Introduction}

Satoyama literally means "village mountains" in Japanese, as "sato" means village and "yama" means mountain. Satoyama defined as "a mosaic of different ecosystem types - 
secondary forests, farmlands, irrigation ponds, and grasslands — along with human settlements, which has been managed to produce bundles of ecosystem services for human well-being". Fundamental to the definition is the Ifugao satoyama with its natural areas and human settlements coexist in harmony, a habitat of abundant plant diversity and various animal lives.

The IRT symbolize not only the Ifugao industry and engineering skills but also their love of freedom $\&$ respect of nature notwithstanding that the IRT has been managed traditionally by their ancestor for survival and existence. The national recognition to protect the IRT started way back 1973 when the late Pres. Ferdinand E. Marcos signed into law Presidential Decree No. 260 recognizing the IRT as national landmark having a high value from the viewpoint of the world culture and considered an "irreplaceable treasure of the country."

There is a need to preserve our cultural traditions and conserve our heritage landscapes, the ancestral knowledge and ingenuity that built the rice terraces should be handed down to the future generation. Through documentation, the people will learn to appreciate and understand the heritage sites, respect the people and treasure the cultural practices in the rice terraces communities, thus this Ifugao satoyama landscape photography project.

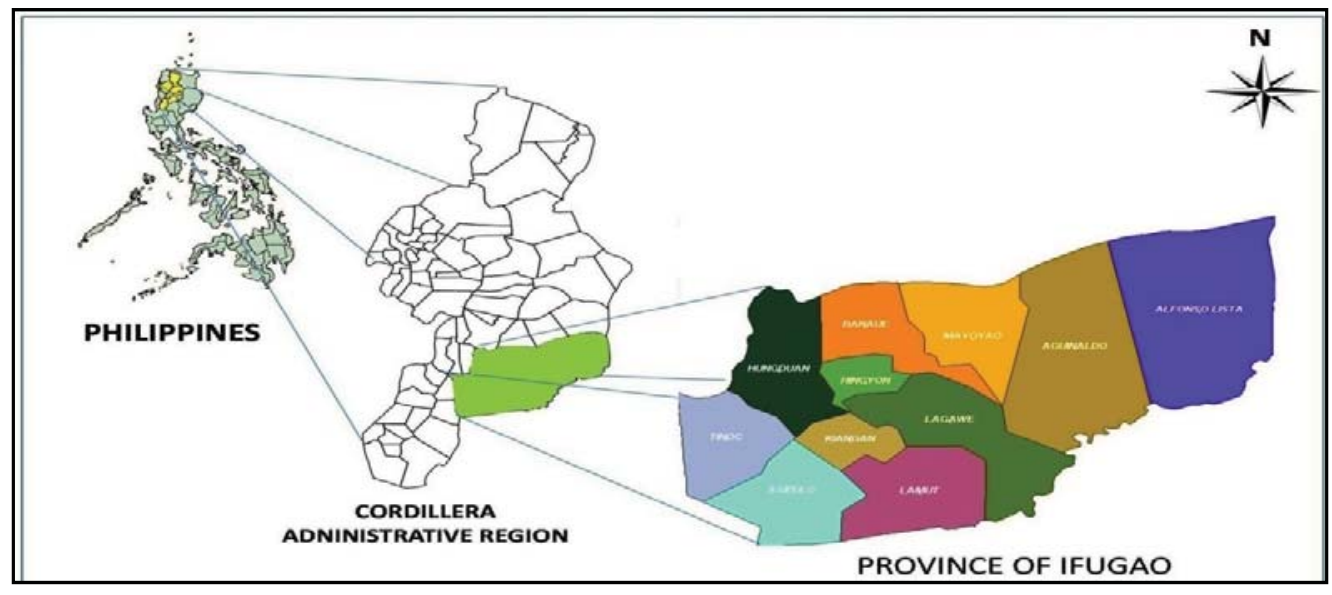

Ifugao is located in Northern Philippines at the foot of the majestic Cordillera mountain ranges (Socio Economic Profile, Ifugao Province, 2007). It is bounded on the north by Mountain Province, on the east by Isabela, on the west by Benguet and on the south by Nueva Vizcaya. It is a landlocked province where there is no outlet to the sea.

Ifugao, a part of the Gran Cordillera Central is generally mountainous. Mt. Napulawan is found in the municipality of Hungduan. Mossy forested with chains of creeks, streams and rivers all around the province. The natural boundaries that surround Ifugao are as follows: Eastern "lagud" side between the province of Ifugao-Isabela is the Magat River; Western "kay-ang" side between Ifugao-Benguet is Mt. Pulag; Northern "huddokna" part between Ifugao-Mountain Province is Mt. Pulis; and on the southern "muyadna" portion lies the Lamut river that separates Ifugao and Nueva Vizcaya, (DENR, CY 2007).

This study was conducted in the four chosen municipalities of Ifugao from the eleven registered municipality. The satoyama landscape covered in the study are the following rice 
terraces in the municipalities recognized by the United Nations as a world heritage; the whole of Hungduan Rice Terraces, the Batad Rice Terraces and Bangaan Rice Terraces of Banaue, the Central Mayoyao Rice Terraces of Mayoyao, and the Nagacadan Rice Terraces of Kiangan.

In the Ifugao Satoyama landscape, what the people make out of their given environs spell the kind of beliefs, customs and traditions they have. The kind of landscape in a way determines to a large extent towards conservation and preservation of the heritage and culture of the people.

\section{Results and Discussions}

\subsection{Eco-evolution of the Ifugao Rice Terraces}

Ifugaos have no written history regarding evolution of rice terraces, however, foreign scholars cited three theories and one local author with his own study and analysis.

The first is H. Otley Beyer of his theory that the ancestors of the Ifugao belonged to the first wave of Malays who came from the Philippines from the Southeastern part of the Asian continent many years ago. They occupied the area around the Lingayen Gulf. After a long period of time their descendants moved up, following the Agno River through Benguet. Coming up to Bokod, they crossed the ridge over to the Kayapa, Beyer wrote, that they settled and built rice terraces. After many years, the descendants of these people moved northeast into ifugao. They passed through what are now the municipalities of Asipulo, Kiangan and Hingyon and proceeded to Banaue, where they began the construction of the first rice terraces in Ifugao. One of the Beyer's bases of his theory on the migration path of the Ifugao from Pangasinan to Ifugao is that the rice terraces in Kayapa, according to him, are older than those in Banaue. This theory, specifically on the migration movement from Pangasinan to Ifugao via Benguet and Kayapa, has raised serious doubts and questions among scholars in recent years.

The second theory of Felix Keesing, he stated that the present-day Ifugao are descendants of a people who lived in Central Cagayan Valley. Fearing the Spaniards who where then subjugating Cagayan and Isabela, these people gradually retreated, following the Cagayan River upstream. After reaching the Magat River, a tributary of the Cagayan River, some went straight to Nueva Viscaya, while the rest returned right and entered the mountains in what is now Ifugao and ended their final flight from the Spaniards. One basis of Keesing for his theory was his "discovery" of the presence of an area near Carig (now Santiago) which appeared to be terraced and where some gabi plants were found. Since rice terraces are common in Ifugao and the people raise gabi, Keesing included that the fields and gabi plants found in Carig were abandoned by the Ifugao when they retreated farther into the mountains of Ifugao. On careful reflection, one realizes that rice - terraces building are not a monopoly of the Ifugao; neither is gabi is propagated exclusively by them. Rice - terraces construction was practiced or resorted to by people in Southeast Asia who live in sloping or steep places. Gabi, too, which belongs to the taro family, is cultivated worldwide.

The third theory is that of Barton. In his book Mythology of the Ifugaos, Barton claims that "Ifugaoland was settled by migrations from various directions that displaced the aboriginal 
Negritos." First, he says that "A migration of kankanai, or proto-kankanai, from across the Cordillera to the west" entered Ifugao. A proof of migration is "the very close kinship between the Kankanai and the Ifugao languages." The second migrating groups includes "the Ifugao of the Lamot valley, to the south (who) speak a different language from other Ifugaos, then there are the Ifugaos of Lagawe (who)had a secret language for which they were famous and in which a few of them could converse."Barton further indentifies the "Silipanes" found in the eastern foothills who were dry rice cultivators and "have a different religion and speak a different dialect from other Ifugao." He also includes the Mayoyao (who) "have a markedly different pantheon and ritual, a different dialect with some lexical differences, different color preferences and ornamentation." He mention to those on the Tinoc region who migrated "from Benguet during the American times." Except from the proto-Kankanai who migrated from the Cordillera to the west and those in Tinok region who came from Benguet, Barton does not mention where the other Ifugao groups originated, although at the start he asserts that "Ifugaoland was settled by migration from various directions."

The fourth theory on the origin of the Ifugaoland their migration to their present habitat is the one held by Mr. Manuel Dulawan. This theory is in agreement with Beyer's assumption that the Ifugao's great ancestors came by crude boats from the southeastern part of Asia and landed on the western coast of Luzon. However, the author stated that the ancient Ifugao, sailing on their balangay, landed somewhere on the La Union-Ilocos Sur coast. Moving eastward to the mountain region, descendant of the Malays who had settled in the Ilocos reached the central part of the Cordillera range, specifically what are now Western Mt. Province and Northern Benguet. Gradually, with the passage of time, descendants of this group who had settled in Tadian-Bauko area scaled the Mount Data Range, crossed the ridges and descended to Ahin and Wangwang in western Ifugao. Descendants of this group later followed the river downstream to Abatan and habangan. From this points, they spread out, some to Hungduan, Banaue and Mayoyao, others to Kiangan, Hingyon, Lagawe and Asipulo. It was the descendants of the first settlers from Tadian and Bauko whom the Spaniards first found when they entered Ifugao from Nueva Vizcaya in the middle of the 1700s.

\subsection{Life in the Rice Terraces in Harmony with Nature (Photo Exhibit)}

\subsubsection{The Payoh}

The following characterization of the payoh is best illustrated in pictures for better understanding and appreciation. 


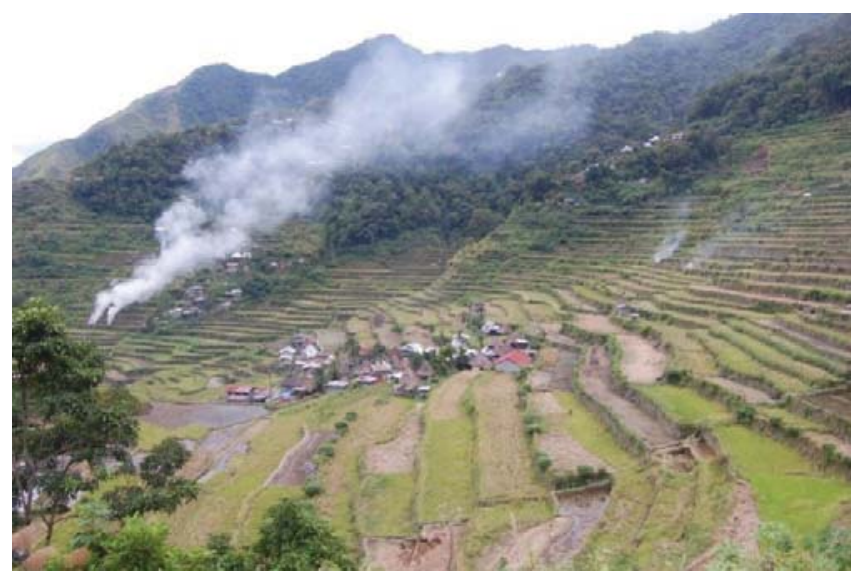

2.2.1.1 The major characteristics of the Ifugao RiceTerraces landscape are the series paddy rice terraces constructed along the contours of the mountain slopes and the forest locally called Muyong on the upper portion of terraced paddies (payoh)

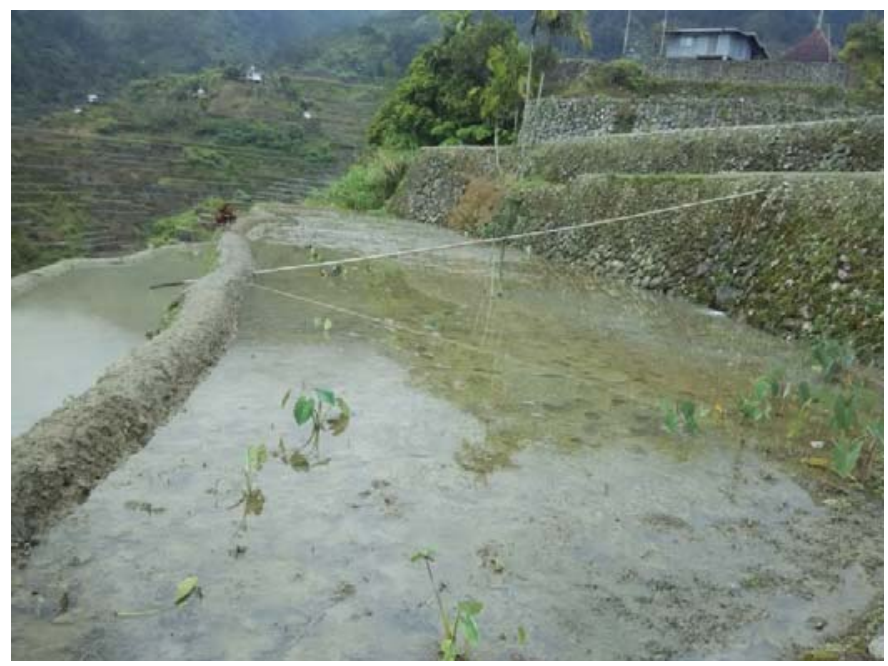

2.2.1.2 The carved out of steep slopes and reinforced with stone walls, maximize the use of water and land resources.

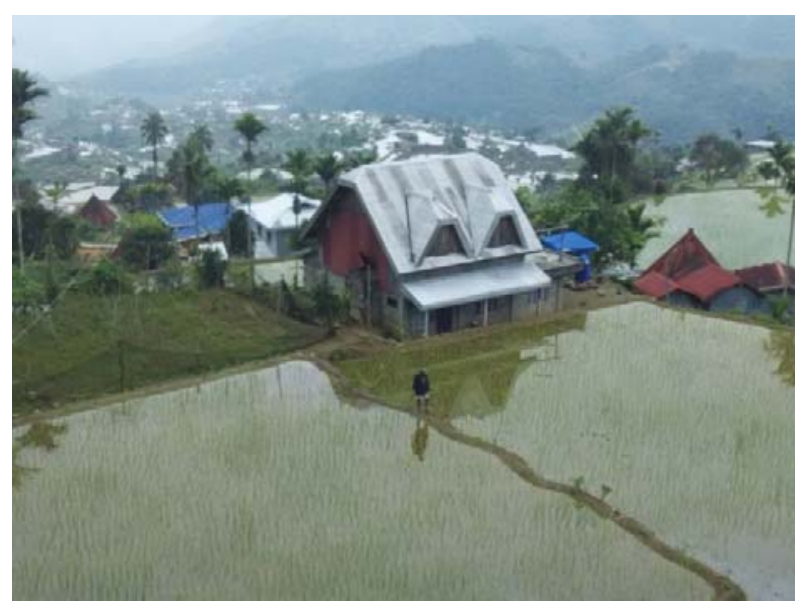




\section{MInstitute ${ }^{\text {Mut }}$}

2.2.1.3 The payoh is privately owned and primarily planted with traditional varieties of irrigated rice as documented. There are two types of rice terraces-forest coupled agroforestry systems, the stonewalled rice terraces and the unstonewalled rice terraces.

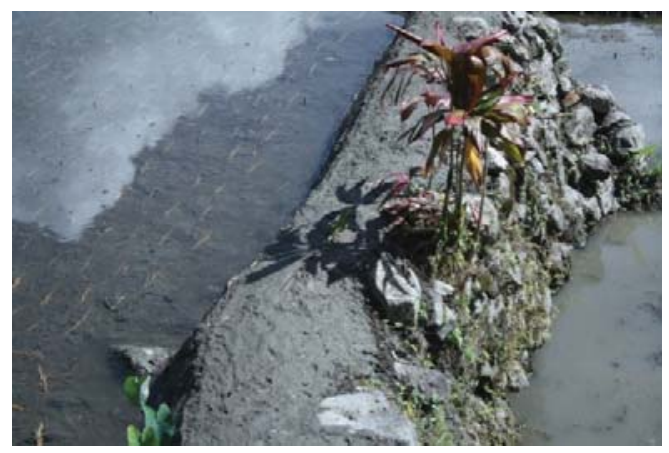

2.2.1.4 Boundaries are carefully delineated and distinctly marked with the red dongle plant (Cordyline fruticosa) along the rice paddies or dikes.

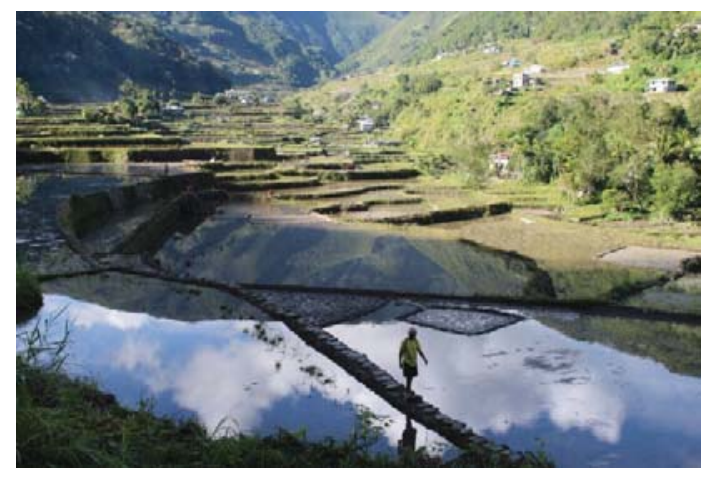

2.2.1.5 Payoh is always wet and flooded and terraced done from the bottom to the top of the slope.

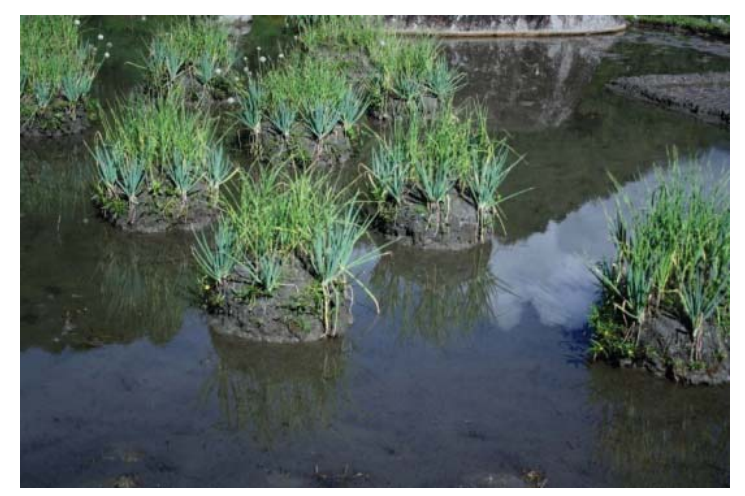

2.2.1.6 Small compost mound called kinago/pingkol are also formed in is the pond field during land preparation, where some vegetables are planted. 


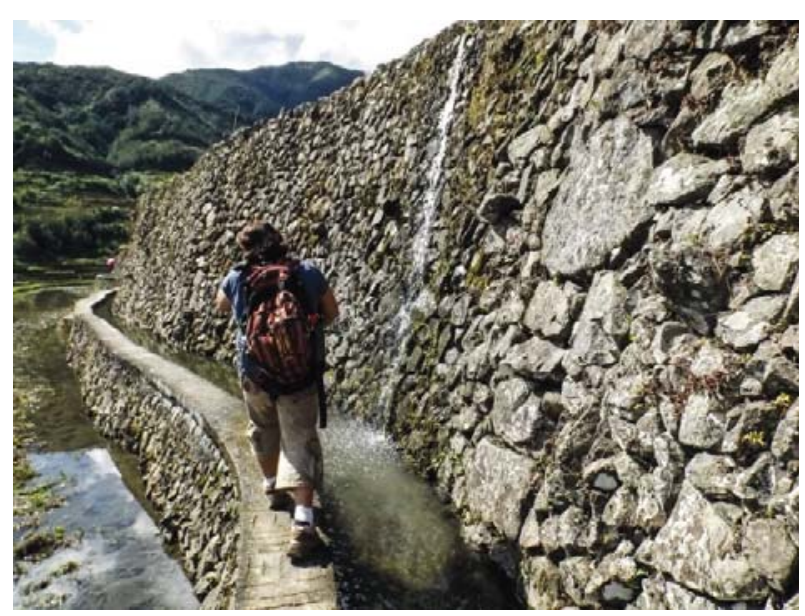

2.2.1.7 It is usually reinforced with stonewalls, to maximize the use of the land and water resources.
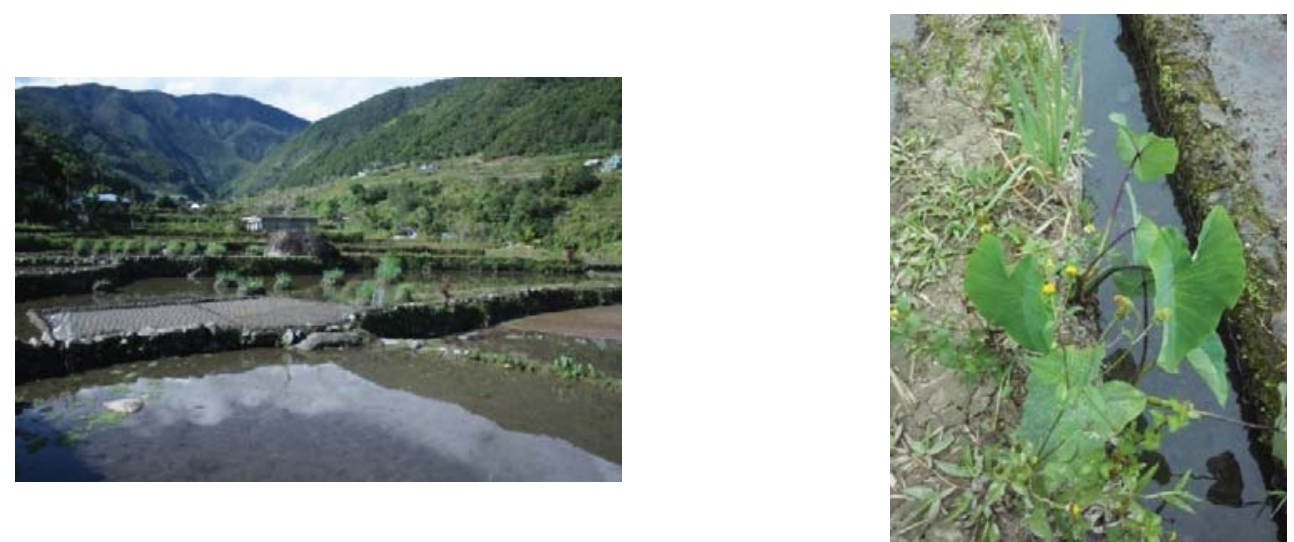

2.2.1.8 Agricultural cash crops (gabi, camote, cassava and chili pepper) are being cultivated in pingkol/kinago or along dikes and boundaries of payew in the sampling areas.

After the harvest season, vegetables are grown in organic mounds (pinkol) and flat organic beds (inado) while fish are raised in fish holes (luhok) built inside the terraces. Off season fishing is observed during the booting stage of rice. Thus, fishes and shells are readily abundant immediately after the harvest season. The sustainability of rice terraces depends on the availability of water and the physical integrity of the terraces to hold water. 


\section{MInstitute ${ }^{\text {Mink }}$}
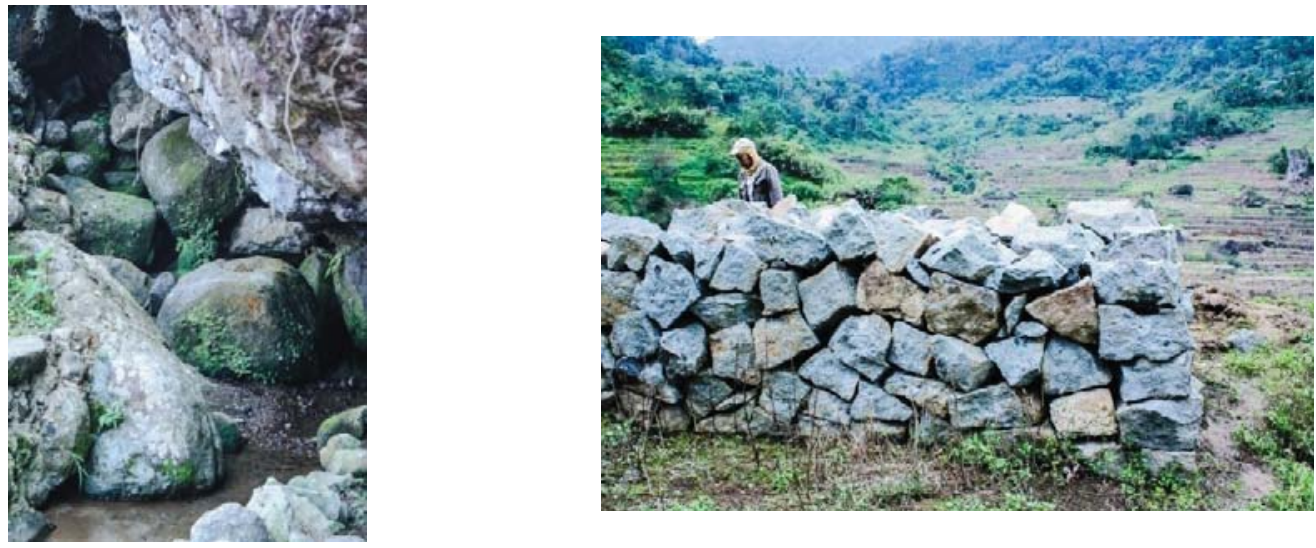

2.2.1.9 Stone Works. Different stones are use for stone walls. The stages of stone walls construction are followed by the folks. During rice terraces construction engineering principles and techniques are perform like in sites selection, hydraulics, retaining walls, random bonding, buttressing, water sealing, irrigation and drainage system. Construction processes are being followed during stone walling, backfilling, maintenance and repair.

\subsection{Human Nature Interaction on the Rice Production Cycle and Cropping Patterns}

Photographs were taken inspired from the discussion of Culhi(1982), the following photo-exhibits were taken from the four heritage sites during the photo-session; The rice production cycle is based on the Ifugao calendar as presented in the diagram;
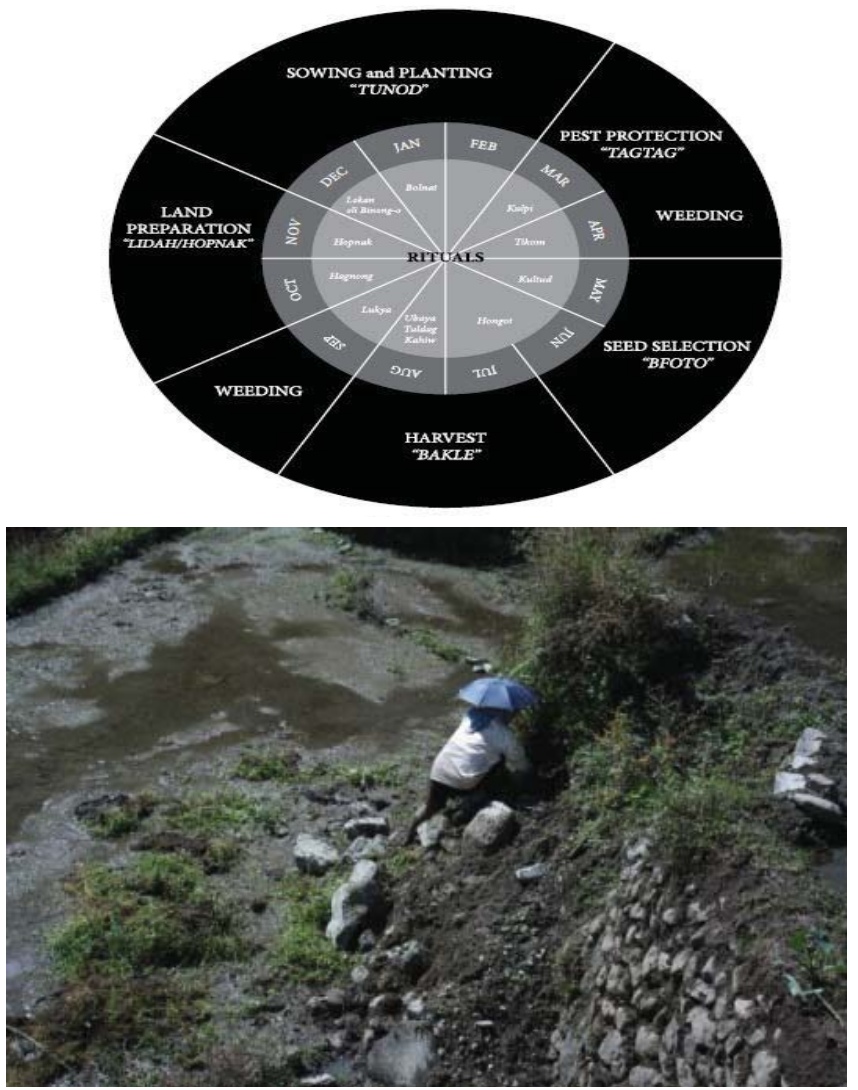


\section{Macrothink}

2.3.1 Ahilamun- cleaning of the rice fields

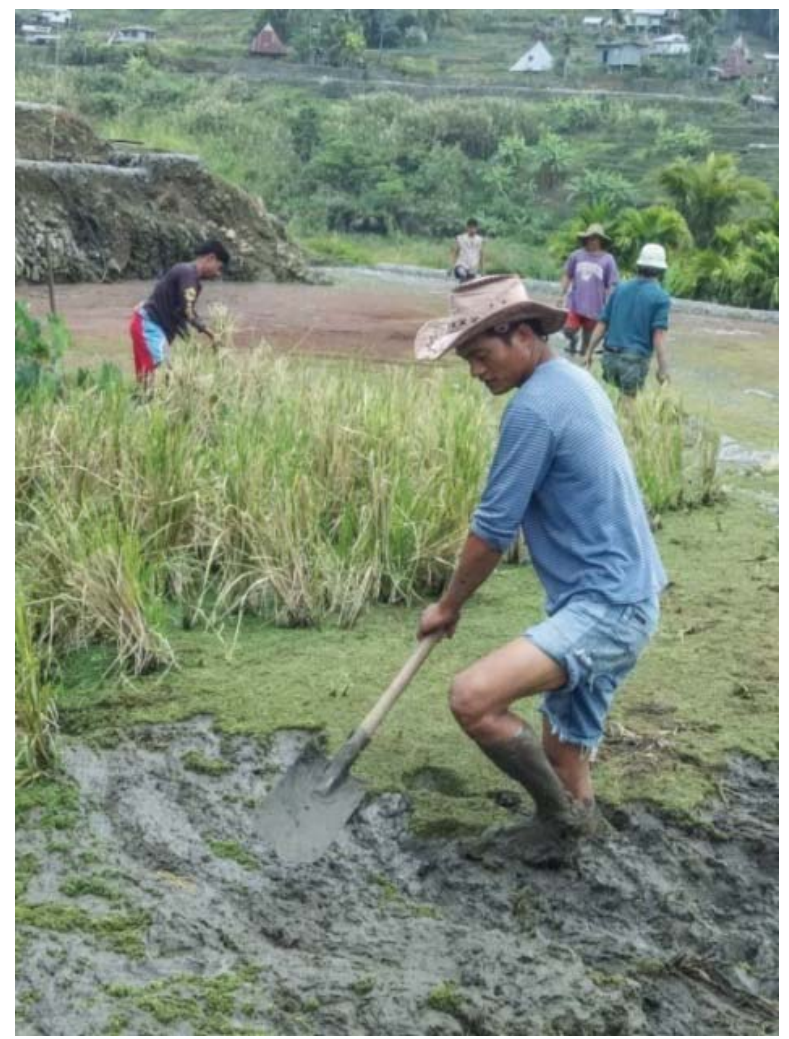

2.3.2 Ahihukle- digging and turning the soil in the rice field;

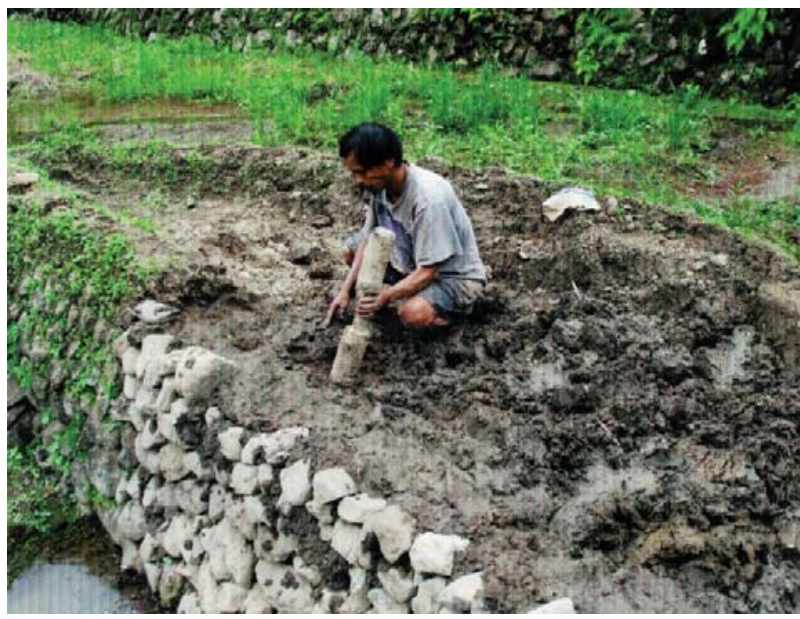

2.3.3 Ahigaud- maintaining and reshaping the terrace slopes; 


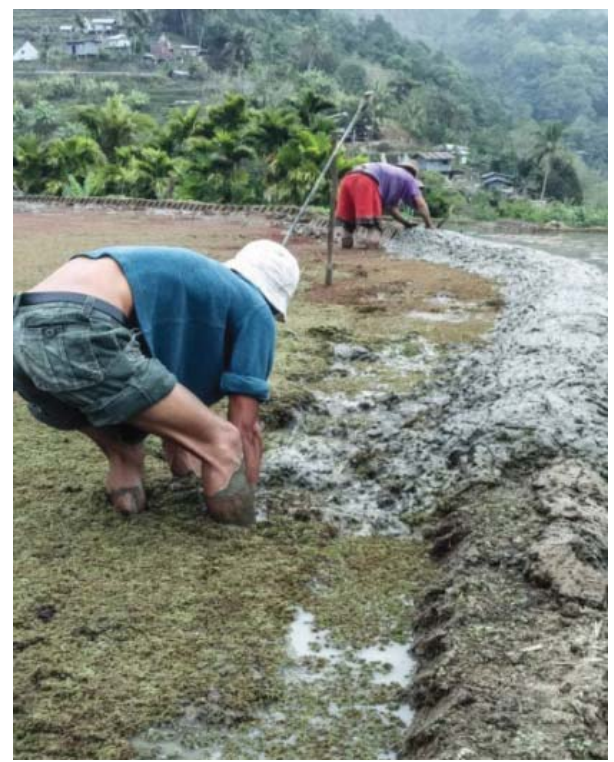

2.3.4 Munpejpej / Ahibanong - before the planting season, the banong is appraised, the worn-out paddy is trimmed and fresh mud is placed on the side and on top to plug leaks in the dike.

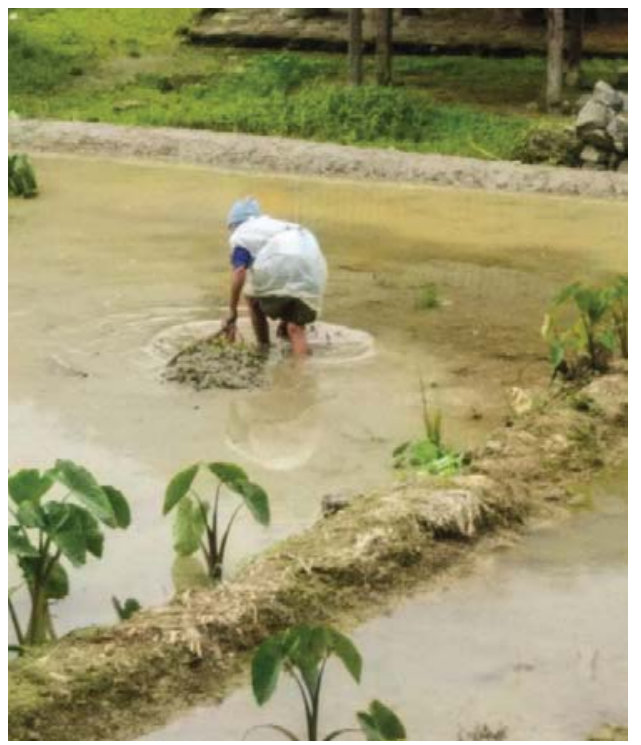

2.3.5 Ahibalin- second weeding and wet mulching time done by women; 


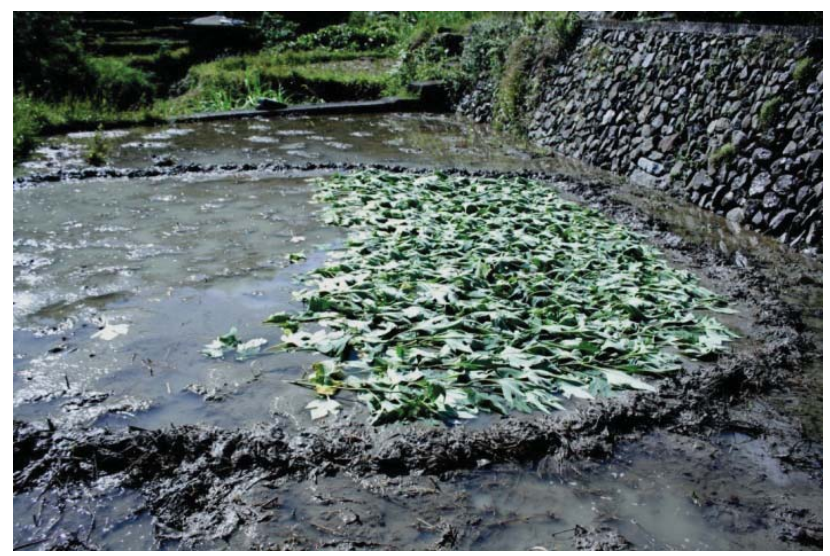

2.3.6 Ahipaphod-selection and maintenance of the seed bed "panopnakan".

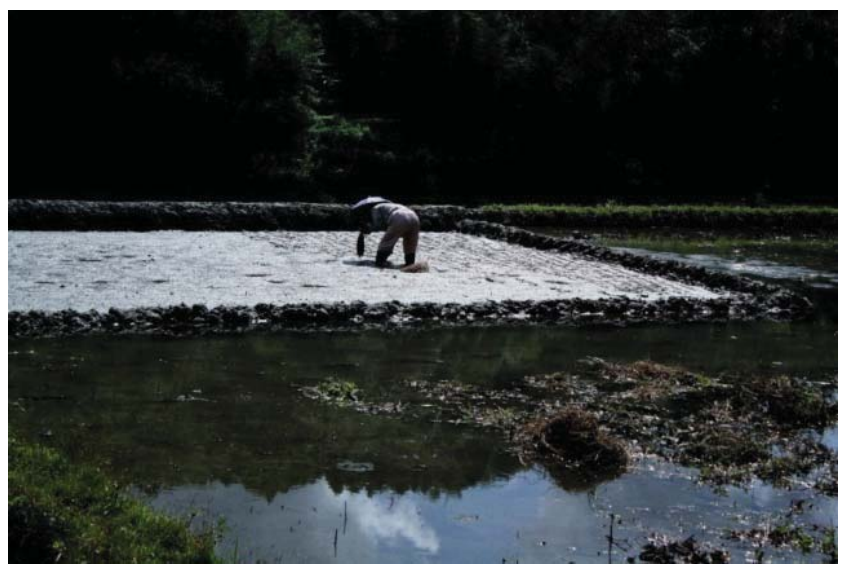

2.3.7 Ahihopnak- laying of rice seeds in the seed bed

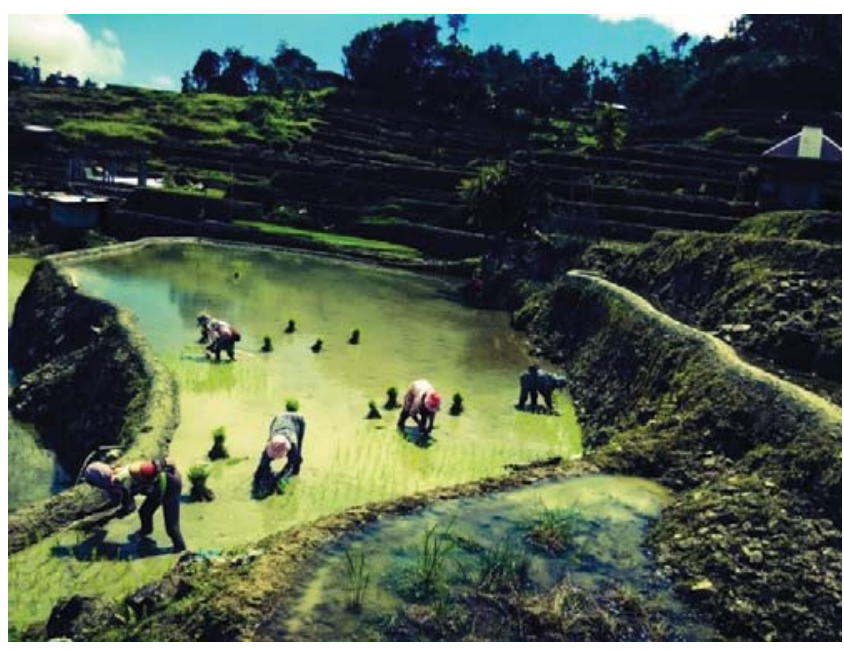

2.3.8 Ahiboge- rice transplanting 


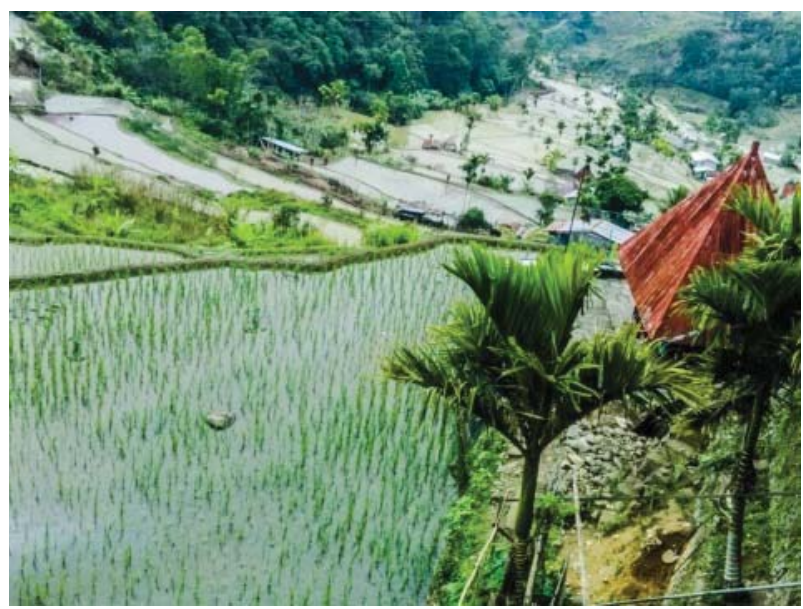

2.3.9 Ahikipi-completion of the rice planting

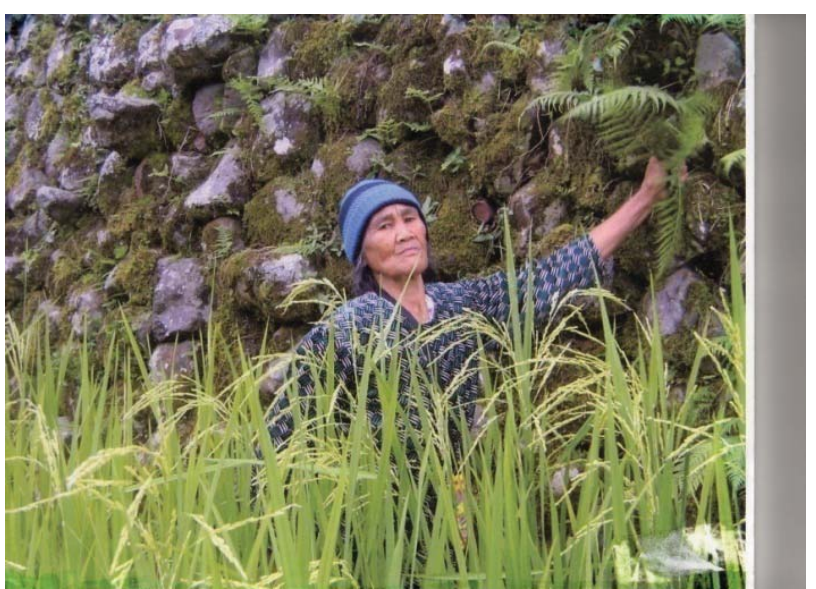

2.3.10 Ahiloba- wall cleaning

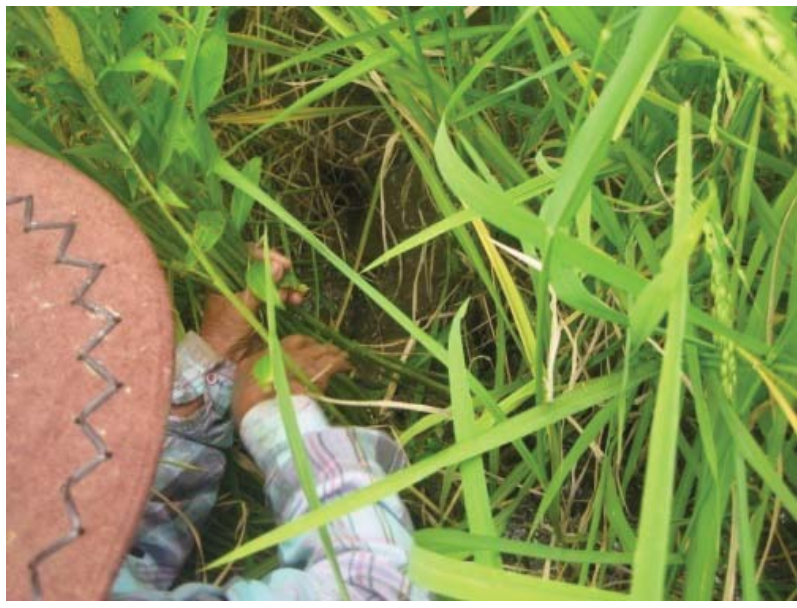

2.3.11 Ahikagoko-weeding between rice plants done by women 


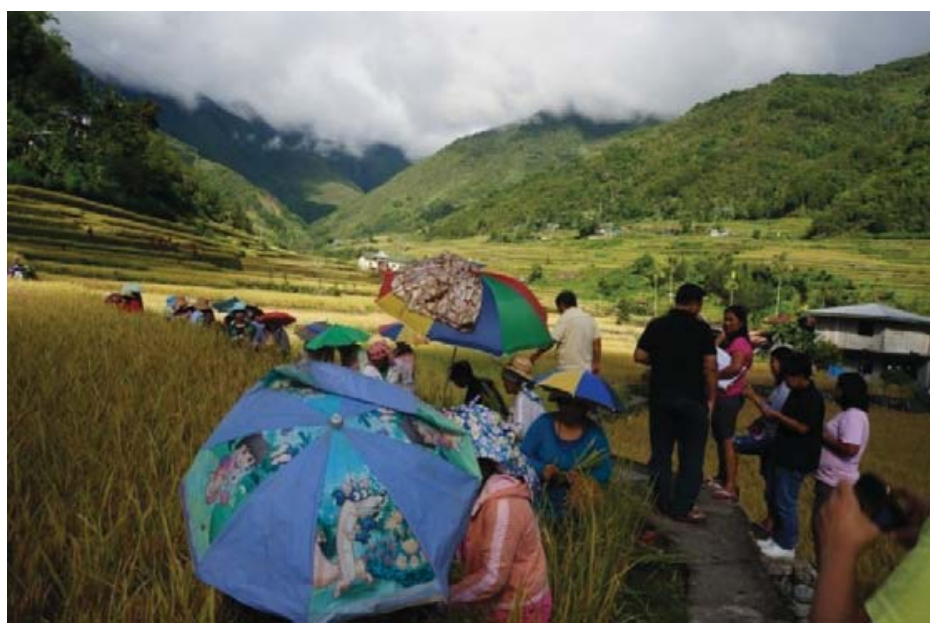

2.3.12 Ahiani-rice harvesting

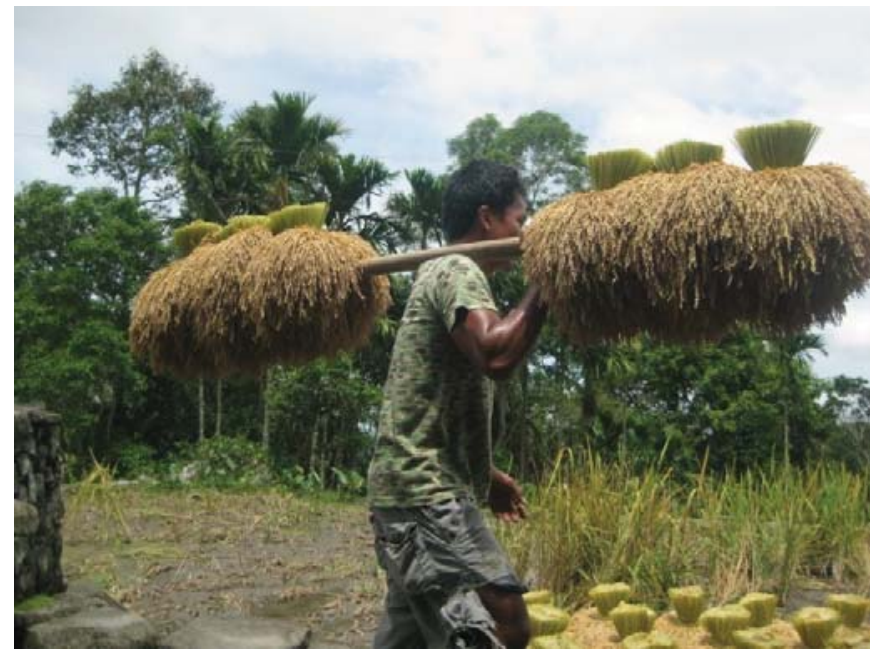

\subsubsection{Ahihadang-rice hauiling done by men}

In the Ifugao agricultural calendar, there are two major seasons in the rice cycle, the "hiwang" is the period of abundant rice supply and " tialgo" is the season of rice shortage. Tialgo is frequently experienced in between the seasons of rice planting to harvesting.

\subsection{IFUGAO Satoyama Landscape.}

\subsubsection{The Umah-Habal (Swidden farming/ Kaingin) and Ublag (Fallow Farms)}

Swidden farming or habal is said to be the oldest form of agro-foresty. Portions of land in the mountain slopes, in the valleys, or in plains which are not irrigated are used for swidden farming by the farmers. The land is cleared, burned, then plante with crops other than rice to supplement whatever harvest they have in the rice terraces. 


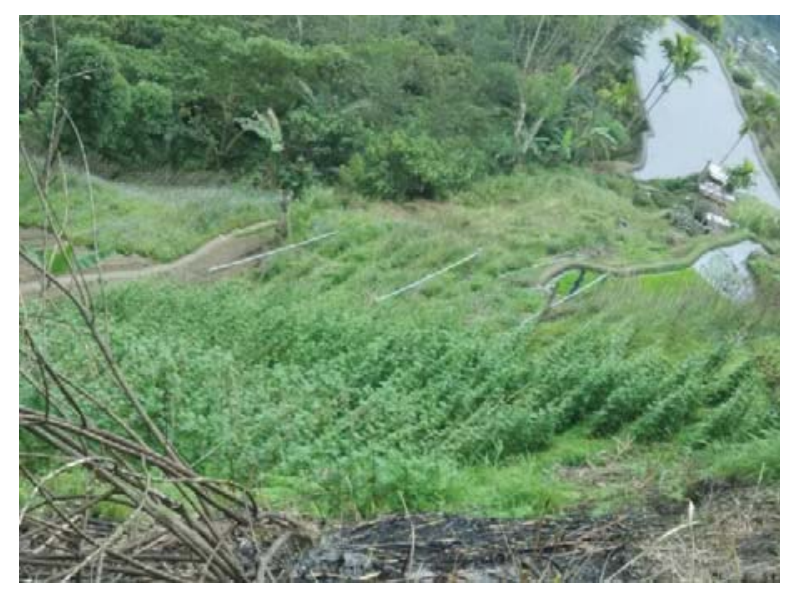

2.4.1.1 It is being practiced by the Ifugaos in limited scale.

2.4.1.2 A household may maintain one or two Habal at a time.

2.4.1.3 Management practices include traditional mixed planting; minimum tillage for soil conservation and enhanced fallow.

2.4.1.4 During the fallow periods or Ublag, seeds from adjacent Muyong will regenerate the umah/habal and new Muyongs are later allowed to develop.

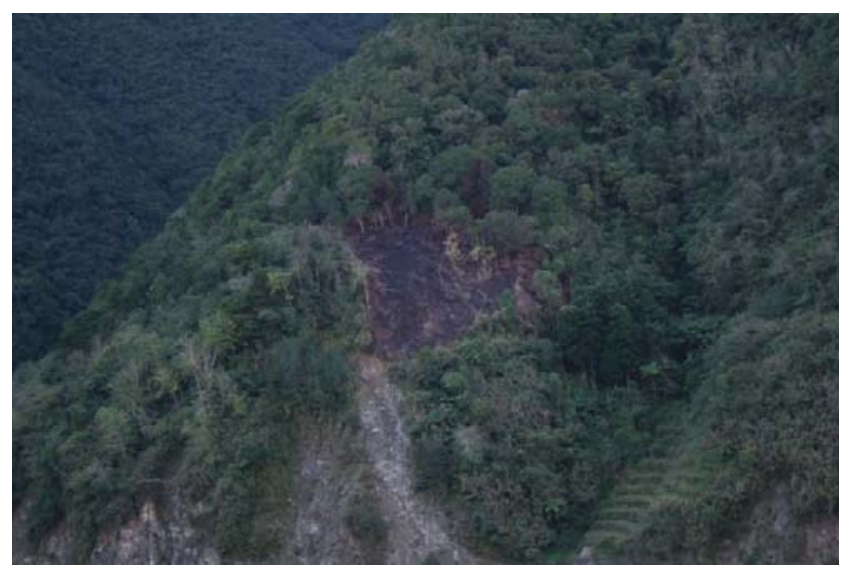

Then practice of cut and burn is being practice at present with intercropping - the comote is intercrop with pigeon pea, cucumber squash and ginger, and the crop rotation - mongo production to camote production.

\subsubsection{Muyung (woodlot)}

Muyung simply means forest. After the hapfar has been abandoned and there are trees grown in the area, the operation will be cleaning under the trees as manifestation that he is the owner. He can plant additional seedlings if there is more space. Not just anybody can go and cut trees in the area unless permitted by the owner.

When matured trees are cut in the pinuchu the owner or children has to replace with new seedlings. 

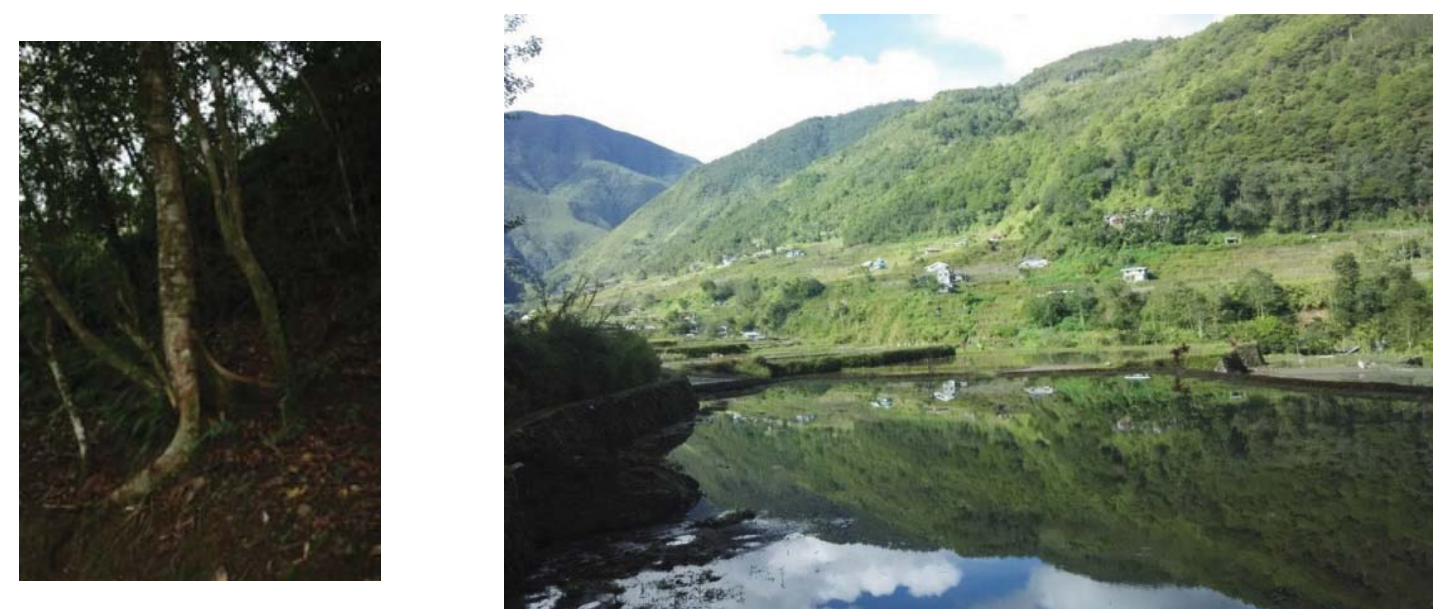

When a family owned muyung is well tended, it is referred to as pinugo, from the word puguwon, which means to grow and tend trees. As a tree lot, the muyung is also utilized for growing fruit trees. The littuko, a cultured variety of rattan found only in Ifugao, are often in tree lots or muyung. The following intensive practices in the muyung as cited by Dulawan(2006); regular cleaning, planting \& replanting, selective cutting, technique of felling, permission to cut, maintenance of boundaries, resolution of boundary disputes.

\subsubsection{Wah-el/Wangwang (River/creeks/waterfalls)}

The rivers are the natural streams of water and mostly are larger than creeks found in Ifugao. The river systems flow from high mountains and follow a north to southern direction. In the province, all the rivers drain into the Magat River and into the Cagayan River.
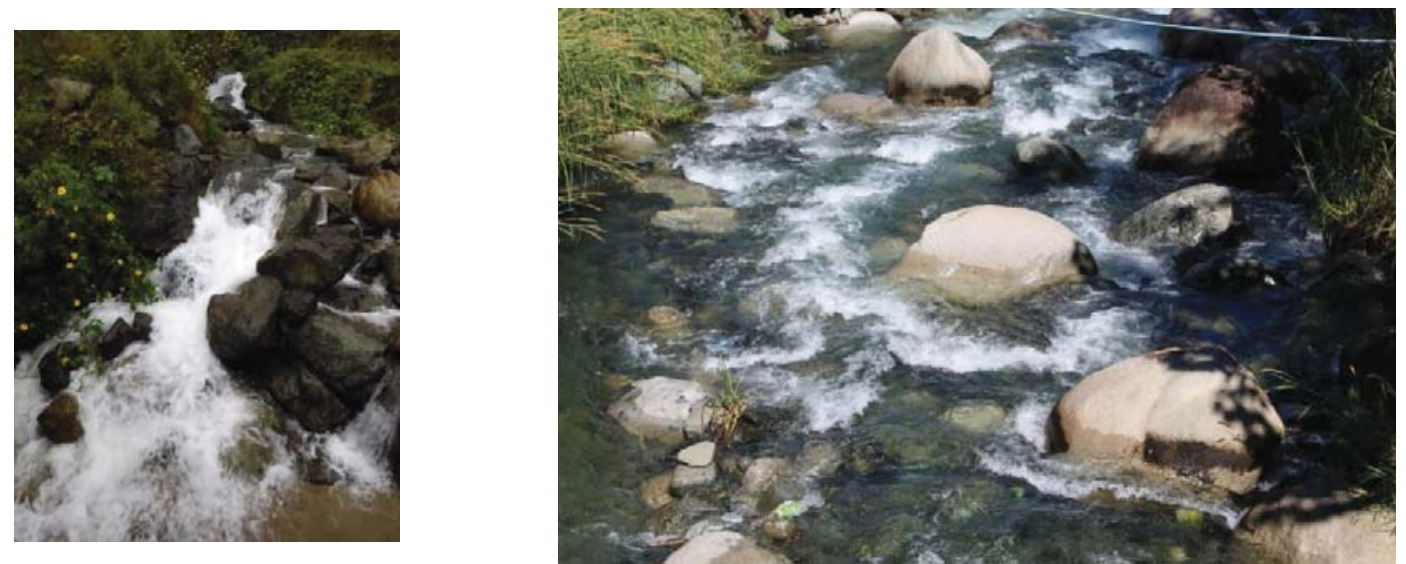

The water from Wael and Wangwang are inland bodies of water like rivers, lakes streams, and springs that give life to the Ifugao Rice Terraces. The Ifugaos have stories of the origin of the different waterforms in their localities.

\subsubsection{Fubloy and Bobleh}




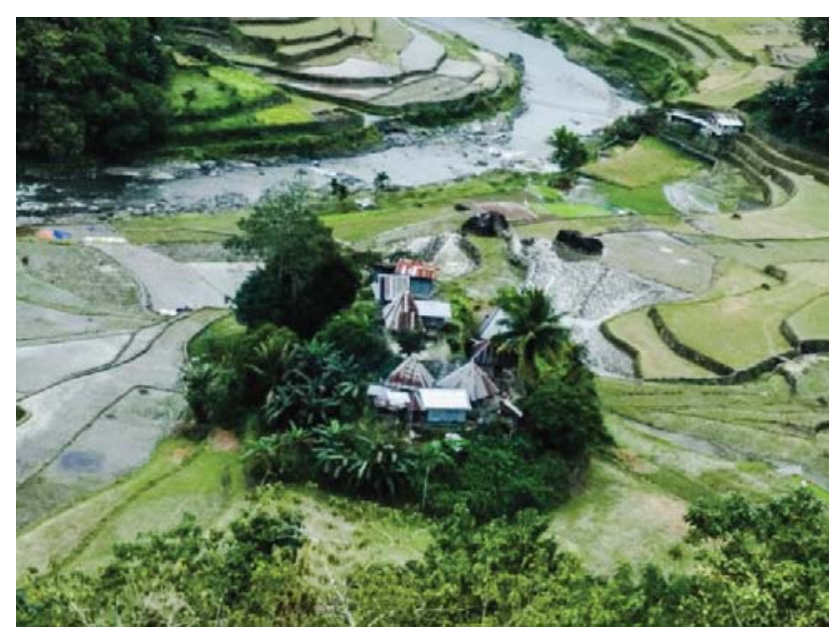

This is the area or a piece of land where the houses of the people are built.In Ifugao, the people live together in villages because, during the early times, they believe that doing so is a deterrent from enemy attack either from people or animals. Generally, the villagers are interralated either by blood or by affinity.

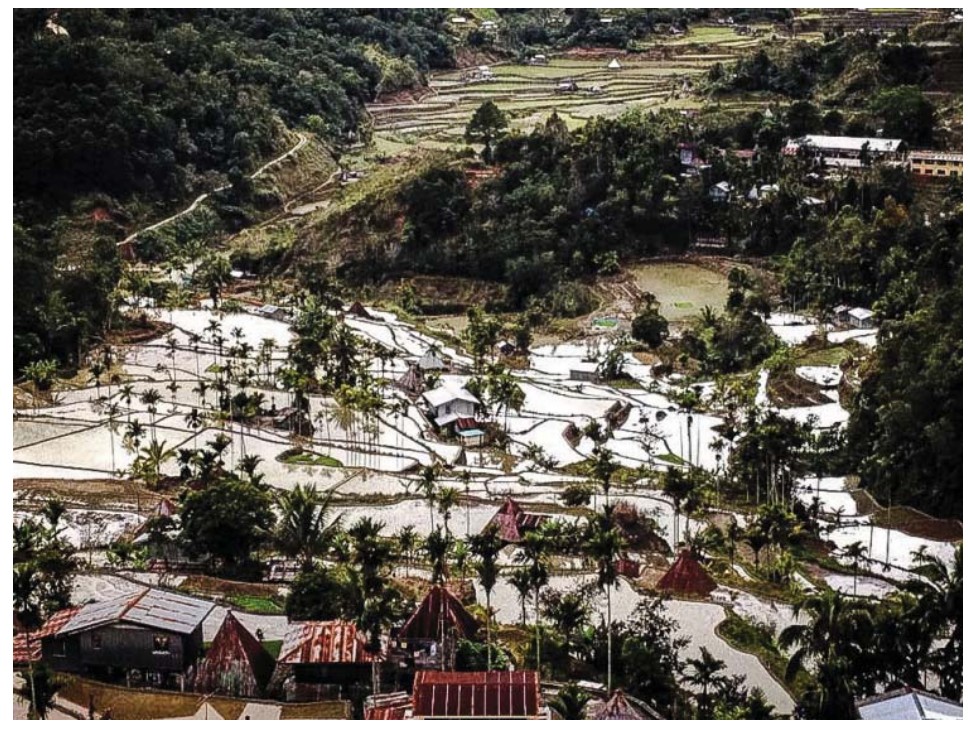

The boundaries of residential areas were defined since then. Even with the passing of long periods of time the current owner, inheritor, or possessor can recount how that particular piece of land came to be. The people in the village could identify the present as well as previous occupants since the close family and village ties are still evident as of this moment. 


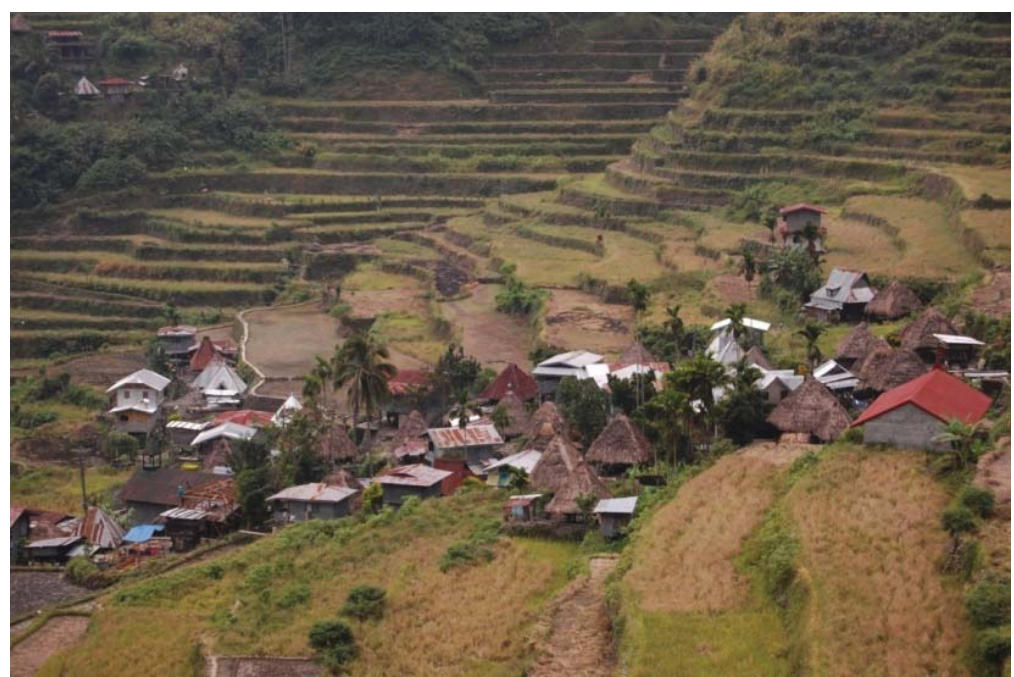

Villages and hamlets are situated in such a way that the people are near the rice fields which is their main workplace and not so far from the forests which is the sourve of fuel and materials for handicrafts and other necessities.

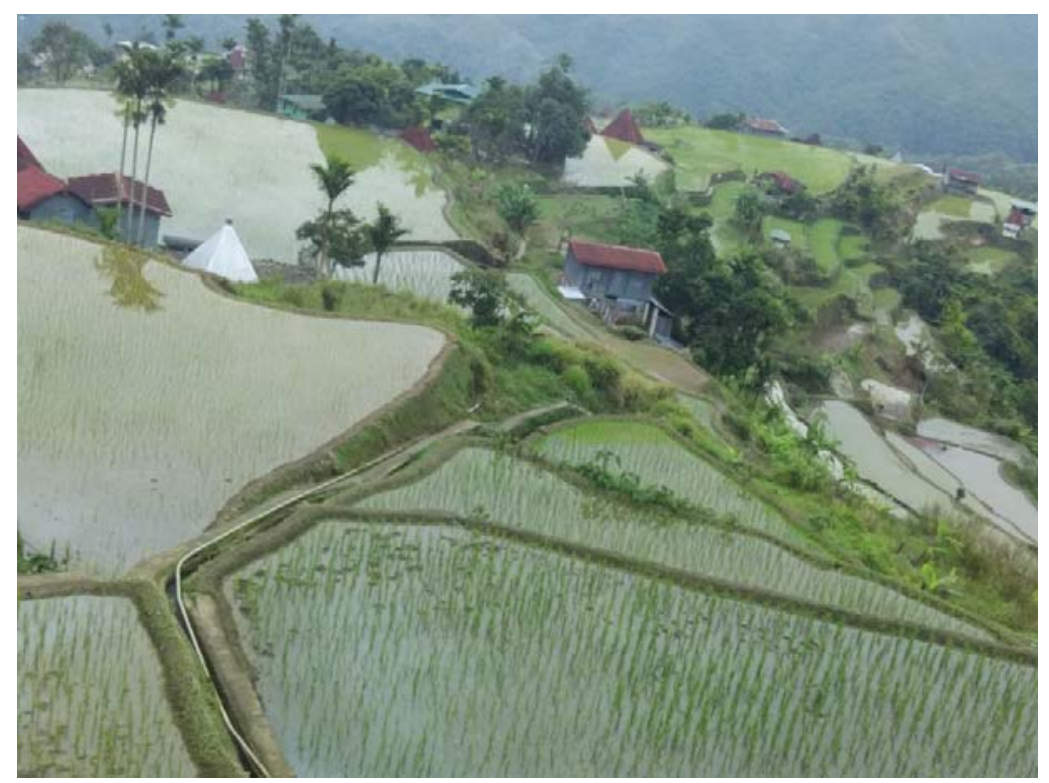

Several dozens of hamlets scattered near a clustered series of irrigated terraces and other land properties compose an average district (himpuntonaan). It has a defined single centrally located rice ritual field (Conklin 1880:5) 


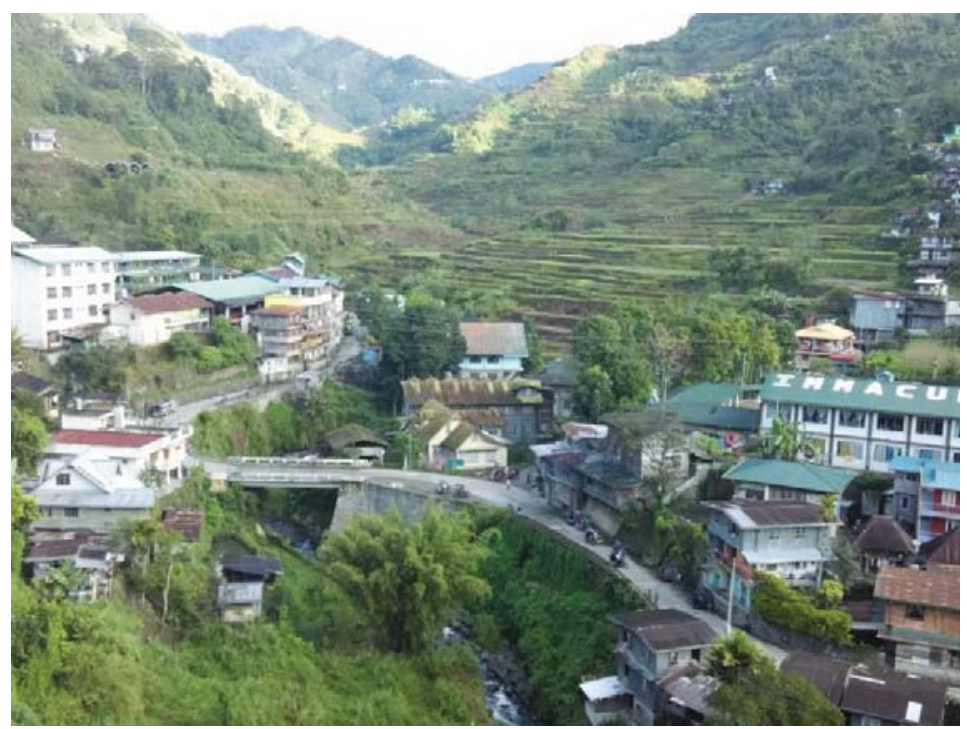

An Ifugao village is composed of many subdivisions with specific names that are adapted from particular relatively level areas. Natural linear terrain borders like streams and rivers are not usually named, although prominent points along the main river valleys have specific names.

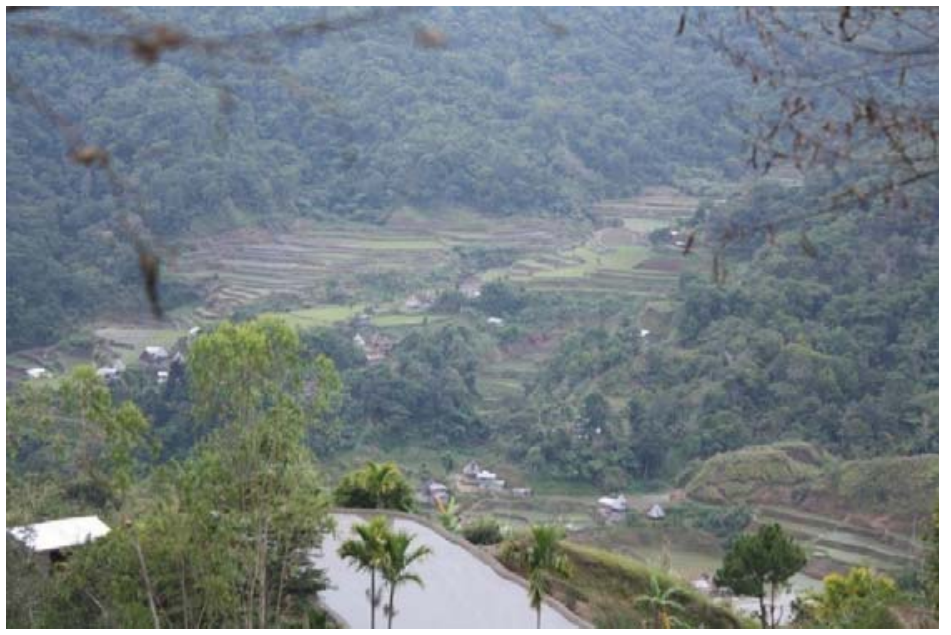

The various barangays become more closely bound to each other by sharing access to essential woodlots and irrigation water. Alignments of several districts often overlap but form the standpoint of village. 

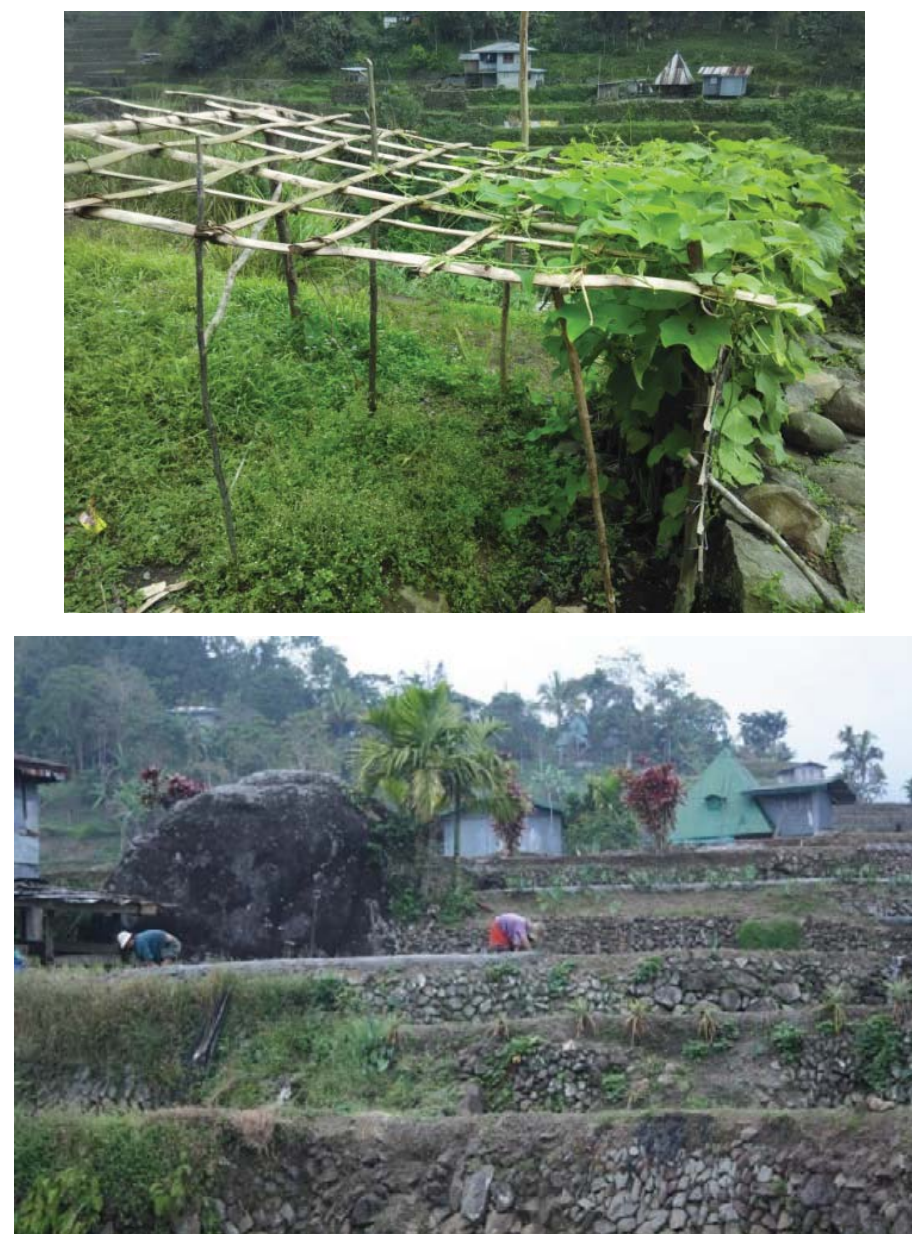

Home garden is composed of agricultural crops, trees and shrubs in the same unit of land, which are produced consecutively and or spatially, mainly for family or community consumption.

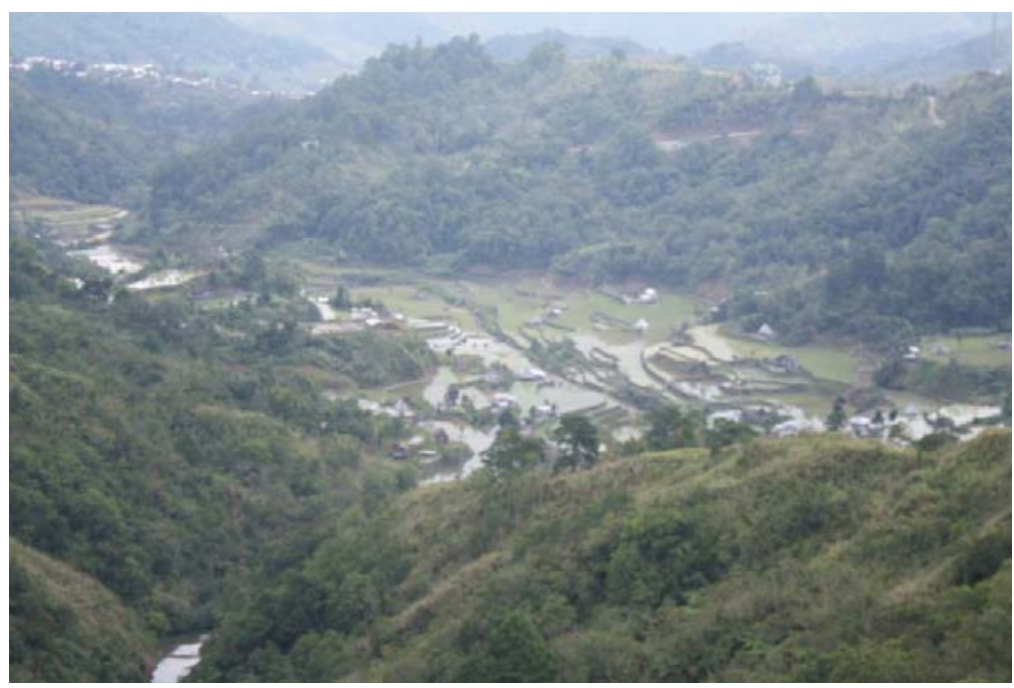

Finally, the Bobleh is preferred to live in a place a little away from the community to be near their rice fields or kaining, forests or besides a river or spring for they are individualistic by 


\section{MInstitute Mach $_{\text {Int }}^{\text {Macrothing }}$}

nature and they love to be free.

\subsubsection{House Construction}

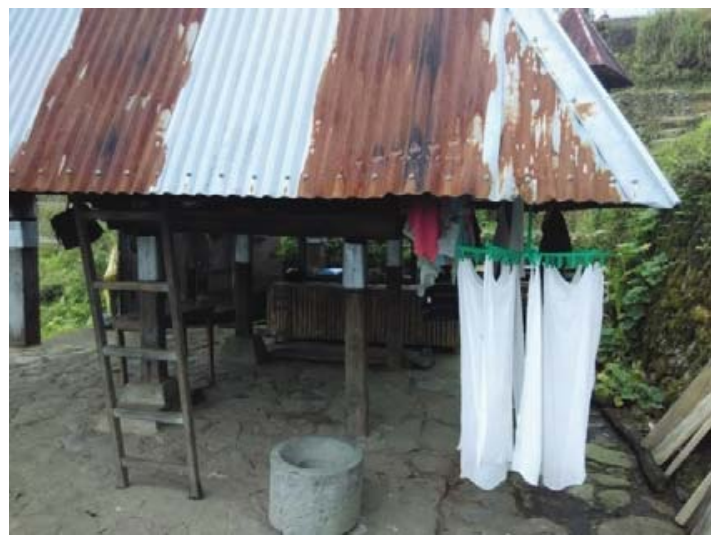

The house is the home of Ifugao family. These are built according to structure and function.
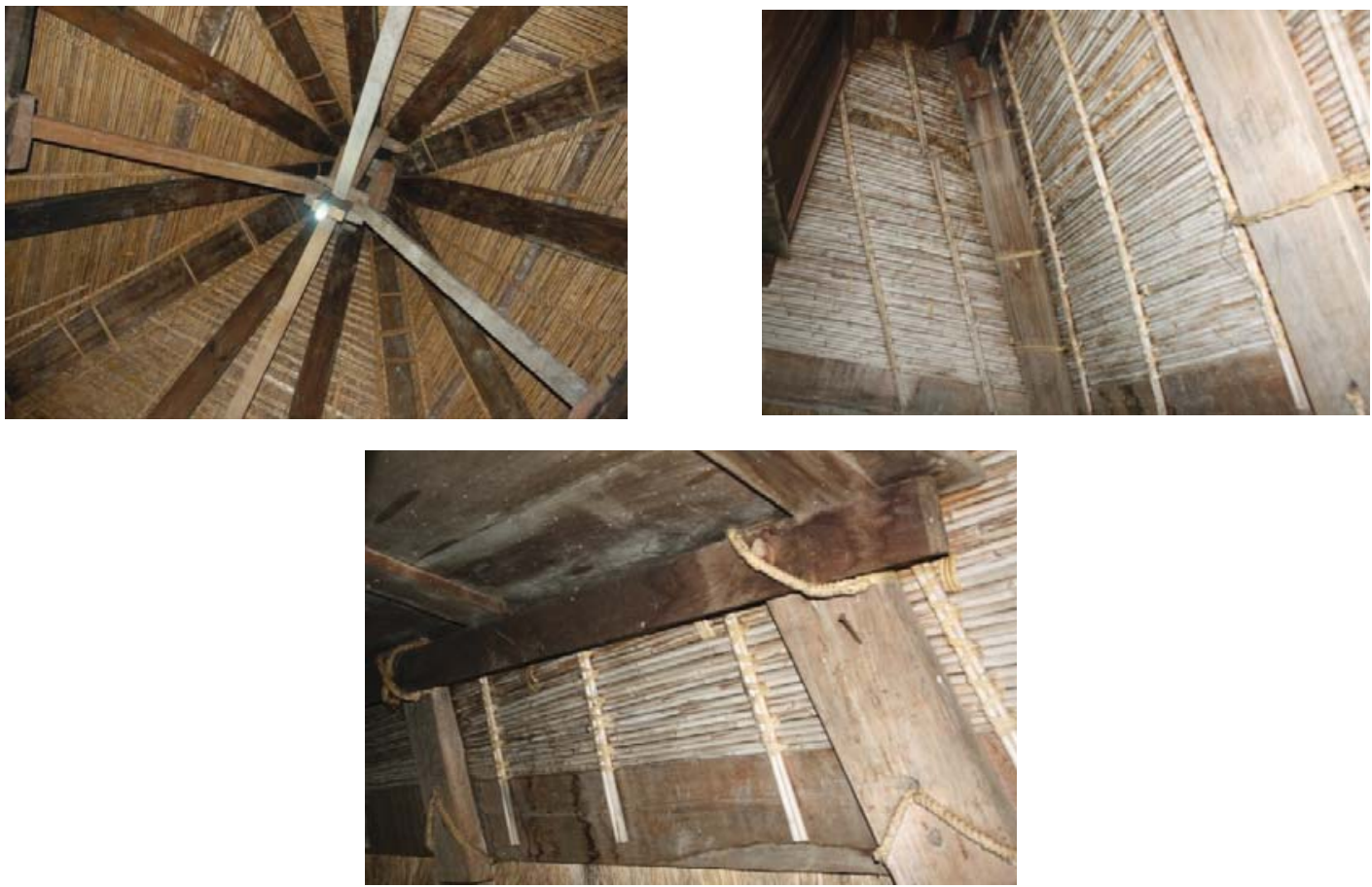

The architecture of the native house is applied on the external parts, the foundation of the house and the interior designing selecting the materials to be seed, the carpenters consider the kind of wood and the materials to be used like in any house construction, the Ifugao makes basic planning and programming before the construction The experts follow strictly the steer in the construction of the house to ensure that it is properly done and safe for the family to reside. Men and women play significant roles in house construction. 


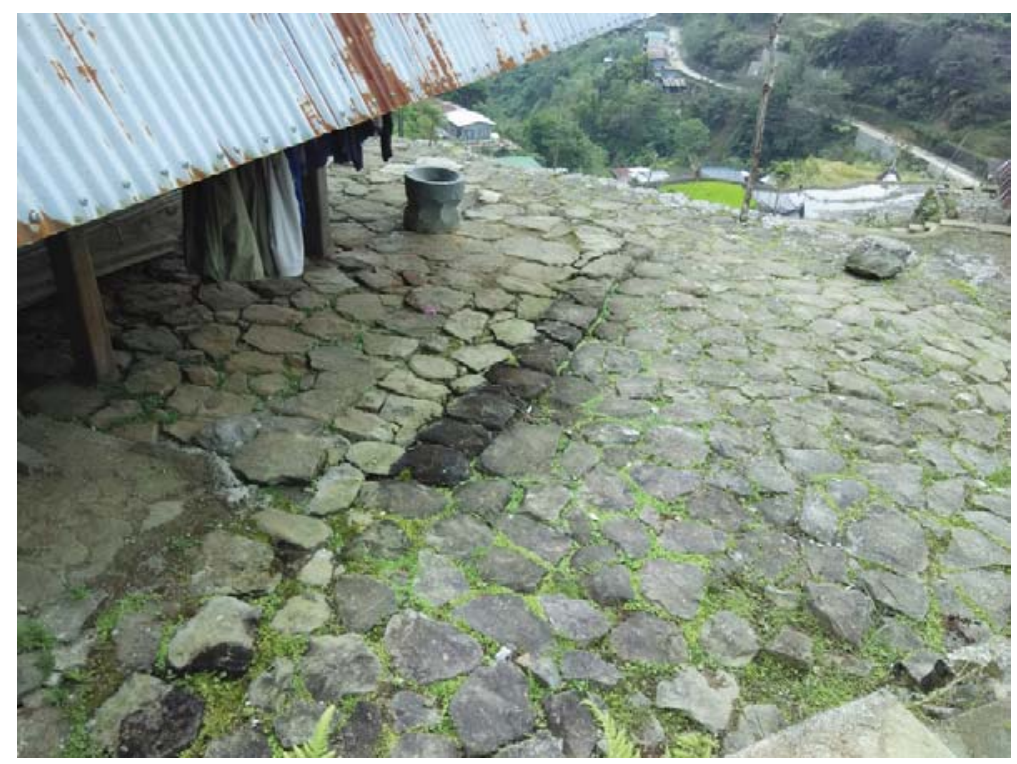

A range of materials and tools are also used by the Ifugao by the stone tilling. Steps are followed in stone tilling in order to tile the ground so it does not get muddy, easy to clean and makes it ideal for drying rice grains and legumes.

\section{Conclusion}

The heritage sites, Hungduan Rice Terraces, Batad Rice Terraces, Bangaan Rice Terraces, Central Mayoyao Rice Terraces \& Nagacadan Rice Terraces proved the excellent forms and aesthetic beauty of the satoyama landscapes. The testimony of the traditional land use and a sustainable system of natural resources depicts the ingenuity of the ancestors that was handed down to us 2000 yrs ago. The payoh, habal, muyong, wah-el/wangwang, \& bobleh has diverse indigenous flora \& fauna as well as introduced species as observed during the photography session.

Accordingly, the satoyama landscape are now in a very critical stage of deterioration. Factors that threaten the sustainability and uniqueness of these GIAHS are as follows;

1) Modernization

2) Unsustainable technological and economic changes

3) Lack of promotion of diversified and economically friendly farming system

4) Neglect of research and development

5) Erosion of rural values linked with outmigration and loss of youth

6) Overexploitation of resources and declining productivity

7) Import of exotic domesticated cultivars

In closing, the Ifugao Rice Terraces is a World Heritage Site and a GIAHS, hence, concerted efforts are needed from line agencies from the local as well as International 


\section{Mll Macrothink}

Organizations to map further support in the sustainability development of the prestigious legacy handed down to us.

\section{Acknowledgement}

The research is financed by the Ifugao State University, and the Ifugao Satoyama Meister Training Program- a program by Ifugao State University, University of the Philippines- OU and Kanazawa University of Japan.

\section{References}

Ethnography of the Major Ethnolinguistic Groups in the Cordillera - Cordillera Schools Group

FAO 2002

IFSU-Museum Collections

Ifugao Biodiversity - GIAHS 2011

National Project for GIAHS-DENR-2008

Nurturing Indigenous Knowledge Experts- Ifugao State University

Oral Literature of the Ifugao- Mr. Manuel B. Dulawan

The Upland Journal 2010 Issue

United Nations University, Satoyama-Ishikawa Journal

What is Heritage for the Hungduan People? University of Tsukuba

\section{Copyright Disclaimer}

Copyright for this article is retained by the author(s), with first publication rights granted to the journal.

This is an open-access article distributed under the terms and conditions of the Creative Commons Attribution license (http://creativecommons.org/licenses/by/3.0/). 